\title{
Ecophysiological interactions and water-related physicochemical parameters among freshwater stingrays
}

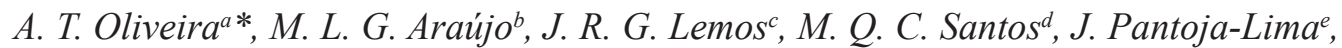 \\ P. H. R. Aridef, M. Tavares-Dias ${ }^{g}$ and J. L. Marcon ${ }^{h}$ \\ anstituto Federal de Educação, Ciência e Tecnologia do Amazonas - IFAM, Campus Manaus Centro - CMC, \\ Av. Sete de Setembro, 1975, CEP 69020-120, Manaus, AM, Brazil \\ ${ }^{b}$ Universidade Federal Rural de Pernambuco - UFRPE, Campus Recife, Av. Dois Irmãos, s/n, \\ CEP 52171-900, Recife, PE, Brazil \\ ${ }^{\mathrm{c}}$ Faculdade Estácio do Amazonas, Av. Constantino Nery, s/n, CEP 69050-001, Manaus, AM, Brazil \\ 'Instituto Federal de Educação, Ciência e Tecnologia do Amazonas - IFAM, Campus Coari, \\ Estrada Coari Itapéua Km 2, s/n, CEP 69460-000, Coari, AM, Brazil \\ 'Instituto Federal de Educação, Ciência e Tecnologia do Amazonas - IFAM, Campus Presidente Figueiredo, \\ Av. Onça Pintada, 1308, CEP 69735-000, Presidente Figueiredo, AM, Brazil \\ Instituto Federal de Educação, Ciência e Tecnologia do Amazonas - IFAM, Campus Manaus Distrito Industrial - CMDI, \\ Av. Danilo Areosa, 1672, CEP 69735-690, Manaus, AM, Brazil \\ ${ }^{g}$ Empresa Brasileira de Pesquisas Agropecuárias - EMBRAPA, Rodovia Juscelino Kubitschek, s/n, Km 5, \\ CEP 68903-419, Macapá, AP, Brazil \\ hLaboratório de Ciências Fisiológicas, Universidade Federal do Amazonas - UFAM, Manaus, \\ Av. General Rodrigo Octávio Jordão Ramos, 3000, CEP 69077-000, Manaus, AM, Brazil \\ *e-mail: adriano.oliveira@ifam.edu.br
}

Received: February 10, 2016 - Accepted: April 26, 2016 - Distributed: August 31, 2017

(With 5 figures)

\begin{abstract}
The objective of this study was to compare and correlate the ecology of neonates and young individuals of Potamotrygon wallacei, Potamotrygon motoro and Paratrygon aiereba with regard to their hematological profile and the physicochemical parameters of the water that they inhabit. Principal component analysis (PCA) on the complete blood count revealed total variation of $72.92 \%$, thus demonstrating a differentiation system for oxygen demand. On the other hand, P. motoro was considered to be an intermediate species, given that its complete blood count characteristics interacted with both $P$. wallacei and with $P$. aiereba. The interaction among the biochemical variables was shown to total $64.67 \%$ of the factors. This allowed differentiation of $P$. wallacei from $P$. aiereba, while $P$. motoro maintained an intermediate position. These characteristics of differentiation within the preferred environment corroborate the PCA of the present study and confirm that these species can be differentiated through considering the complete blood count and biochemical parameters. The PCA on water properties showed $68.57 \%$ differentiation, mainly comprising the $\mathrm{x}$ axis $(49.44 \%)$. It can be affirmed that $P$. motoro has the capacity to inhabit the preferential areas of $P$. wallacei and $P$. aiereba, as well as occupying localities in which other stingrays are not found. In conclusion, $P$. wallacei presents patterns differentiating it from $P$. aiereba, while $P$. motoro is a species that presents intermediate characteristics. The latter can be considered to be a more broadly distributed species regarding its ecophysiological characteristics.
\end{abstract}

Keywords: hematology, potamotrygonids, physiology, differences, ecology.

\section{Interações ecofisiológicas e dos parâmetros físico-químico da água em arraias de água doce}

\section{Resumo}

Este trabalho tem por objetivo investigar o perfil hematológico e os parâmetros físico-químicos da água, comparando e correlacionando ecologicamente entre neonatos e jovens de Potamotrygon wallacei (arraia cururu), Potamotrygon motoro e Paratrygon aiereba. A análise de componentes principais (PCA) do hemograma revelou um total 72,92\% de variação, constituindo-se em um sistema de diferenciação na demanda por oxigênio. $P$. wallacei apresenta diferenciação no eixo X quando comparada a $P$. aiereba, por outro lado $P$. motoro constitui-se como uma espécie intermediária que apresenta as características do hemograma interagindo tanto com $P$. wallacei quanto com $P$. aiereba. A interação entre as variáveis bioquímica demonstram um total de $64,67 \%$ dos fatores, no qual foi possível diferenciar, a arraia $P$. wallacei 
de $P$. aiereba, tendo P. motoro uma aspecto de espécie intermediária entre as demais. Esses aspectos de diferenciação de ambiente de preferência corroboraram a PCA obtida no presente estudo e confirmam que essas espécies podem ser diferenciadas quando se considerar as variáveis referentes ao hemograma e a bioquímica. Nos íons, no trombograma e no leucograma, não foi possível diferenciar as espécies. O PCA das propriedades da água foi constituído por $68,57 \%$ de diferenciação que se constituiu principalmente no eixo x $(49,44 \%)$. É possível confirmar que $P$. motoro tem a capacidade de habitar as áreas preferências de $P$. wallacei e $P$. aiereba, além do mais esta possui uma localidade que as demais arraias não são encontradas. Conclui-se que $P$. wallacei, apresenta padrões diferenciados de $P$. aiereba, além do mais P. motoro é uma espécie que apresenta características intermediárias entre as descritas, o qual pode ser considerado uma espécie com distribuição mais ampla em seus aspectos ecofisiológicos.

Palavras-chave: hematologia, potamotrigonídeos, fisiologia, diferenças, ecologia.

\section{Introduction}

Another characteristic that is common to potamotrygonids is the fear that people have in relation to these elasmobranchs, due to the number of accidents caused by the presence of stings in their tails. During the dry season in the Negro River, is common to develop a process for "cleaning" by capture to harm and/or death of these individuals. This negative fishing needs to be taken into consideration through future environmental education measures, such as: lectures in educational schools, leaflets explaining the ecological and economic importance of this family and ways to prevent accidents (Oliveira et al., 2015a).

In the state of Amazonas, the main location for exploiting this resource is the Mariuá Archipelago, which is located in the midreaches of the Negro River. At this location, exploitation of ornamental fish occurs predominantly in relation to the species Potamotrygon wallacei (cururu stingray; Carvalho et al., 2016) and Potamotrygon motoro (Müller \& Henle, 1841) (Brasil, 2008). However, Paratrygon aiereba (Müller \& Henle, 1841 ) is frequently commercialized under the name of a different species (for example, Potamotrygon orbignyi), considering the difficulty that the inspection agents of the appropriate bodies have in identifying species.

The differences among these species ( $P$. wallacei, P. motoro and $P$. aiereba) go much further than coloration patterns. Potamotrygon wallacei is of smaller size and can reach $45 \mathrm{~cm}$ in disc width. This species is still undergoing scientific description, although its identification has been well defined. The cururu stingray presents sexual segregation, with an annual reproductive cycle that is regulated by river levels, involving copula during the ebb period and birth during the dry period (Charvet-Almeida et al., 2005). Its distribution is endemic and restricted to the midreaches of the Negro River, occurring in litter environments, with low water flow and currents, which are typical of igapó (Amazon submerged vegetation) marginal areas. Moreover, this species has generalist feeding habits, including crustaceans, insects and small teleosts (Shibuya et al., 2009).

The species $P$. motoro species is widely distributed across the Amazon basin (Sanchez-Duarte et al., 2014). This species can reach up to $70 \mathrm{~cm}$ in size and also presents sexual segregation, with an annual reproductive cycle composed of copula during the dry season, pregnancy during the flood period and birth at the beginning of the wet period (Araújo, 2011). The habitat of this species include muddy-bottom areas, in which there is a more visible influence of the water flow (personal observation), and its feeding preference is for crustaceans (Shibuya et al., 2009).

Finally, the species $P$. aiereba is large in size, reaching up to $130 \mathrm{~cm}$ in disc width and weighing more than $60 \mathrm{~kg}$. This species presents sexual segregation and spatial segregation according to size, in which young and sub-adult individuals of both sexes tend to remain aggregated in the same area. On the other hand, male and female adults are isolated in different areas (Charvet-Almeida et al., 2005). This species presents widespread distribution across the Amazon basin and is predominantly exploited by commercial fisheries. The preferential habitat of this species is beach regions, with low intensity of water currents (personal observation). Moreover, its preferential feeding item is small teleosts (Shibuya et al., 2009).

Despite these differences in most of the ecological and biological characteristics, there have not been any investigations on the interactions and differences in physiological traits of these species, or on the physicochemical characteristics of the water in which they naturally occur. The objective of the present study was to compare and correlate the ecology of neonates and young individuals of Potamotrygon wallacei, Potamotrygon motoro and Paratrygon aiereba regarding their physiological profile (complete blood count, plasma biochemistry, white blood cell count and thrombogram) and the physicochemical parameters of the water that they inhabit.

\section{Material and Methods}

The Mariua archipelago is considered to be the largest group of freshwater islands in the world, with a total of approximately 1,600 islands. They provide shelter for rich biodiversity of ornamental fish, including the stingray species $P$. wallacei, P. motoro and P. aiereba. Between the years 2006 and 2011, a total of 114 specimens were captured with the aid of a hand net (rapiché) and a head torch, with previous authorization (IBAMA License No. 15116-1). After the fish had been caught, they were anesthetized with eugenol $(0.2 \mathrm{~g} / \mathrm{L})$. The handling and blood sampling procedures followed the recommendations of Oliveira et al. (2012, 2015b).

The size classes were determined based on the disc width (DW). For P. wallacei, the classification followed 
the recommendations of Araújo (1998); for P. motoro, those of Araújo (1999); and for P. aiereba, those of Araújo (2011). After body mass and total length (TL) had been determined, all the stingrays were returned to the locations where they had been caught. The animals were classified as either neonates or young individuals. A total of 38 specimens of $P$. wallace $i$ were caught, 51 of P. motoro and 25 of P. aiereba.

The blood sampled was divided into two aliquots, one for determining the complete blood count, white blood cell count and thrombogram, and another for obtaining plasma and subsequent assaying of the biochemical components and plasma ions. In the complete blood count, the erythrocyte count (RBC) was determined in a Neubauer chamber, while the hematocrit $(\mathrm{Ht})$ was determined through the microhematocrit method and the hemoglobin concentration $\mathrm{Hb}$ through the cyanmethemoglobin method. The following hematimetric indices were calculated based on these data: mean corpuscular volume (MCV), mean corpuscular hemoglobin $(\mathrm{MCH})$ and mean corpuscular hemoglobin concentration (MCHC).

Blood extensions were prepared and stained in accordance with the recommendations of Oliveira et al. (2015b), and these was used to determine the thrombogram and white blood cell count, from the morphological descriptions of Oliveira et al. (2015b). The extensions were used for the total leukocyte and thrombocyte count (Tavares-Dias and Moraes, 2006), and also for the differential leukocyte count, which was based on counting 200 white blood cell types and then determining the percentage of each cell type that was present.

Plasma was obtained through centrifugation at $750 \mathrm{~g}$, and was then frozen in liquid nitrogen $\left(-86^{\circ} \mathrm{C}\right)$ until the time of performing the biochemical analyses. The plasma biochemical variables, such as glucose, triglycerides, total cholesterol, total proteins and urea, were determined through enzymatic-colorimetric methods that were quantified using commercial kits (Doles, GO, Brazil) that were specific for each parameter. Sodium $\left(\mathrm{Na}^{+}\right)$and potassium $\left(\mathrm{K}^{+}\right)$ions were assayed through flame photometry (Micronal b462, Brazil). Chloride $\left(\mathrm{Cl}^{-}\right)$levels were determined through the colorimetric method, using a commercial kit (Doles, GO, Brazil).

The physicochemical properties of the water, such as temperature $\left({ }^{\circ} \mathrm{C}\right), \mathrm{pH}$, conductivity $(\mu \mathrm{S} / \mathrm{cm})$ and dissolved oxygen $(\mathrm{mg} / \mathrm{L})$, were determined at the location where the each specimen was caught, using a multiparameter digital device (Orion 5-Star Plus). Water samples were collected, stored in ice and then transported to the laboratory for analyses of other parameters, such as hardness $(\mathrm{mg} / \mathrm{L})$, alkalinity (mg/L), total ammonia $(\mathrm{mg} / \mathrm{L})$ and nitrite $(\mathrm{mg} / \mathrm{L})$, following the methodology described by Boyd and Tucker (1992). Sodium and potassium levels $(\mathrm{mEq} / \mathrm{L})$ were analyzed through flame photometry on water samples brought in from the field that had been preserved and refrigerated (Boyd and Tucker, 1992), using a Micronal B 462 device.

To assess the interactions or differences among the hematological characteristics and the physicochemical properties of the water, multivariate exploratory statistics were applied, consisting of principal component analysis (PCA). These analyses were divided into complete blood count (6 variables), plasma biochemistry (5 variables), plasma ions ( 3 variables), thrombogram and white blood cell count (10 variables) and physicochemical properties of the water (10 variables). Interactions were considered significant when the sum of the $\mathrm{X}$ and $\mathrm{Y}$ axes was greater than or equal to $60 \%$.

\section{Results}

The DW and body mass results are shown in Table 1 and demonstrate that the $P$. wallacei stingrays were the smallest among the stingrays studied. The PCA on the complete blood counts (Figure 1) of the three species of stingrays studied revealed a total variation of $72.92 \%$. It is possible to observe that $P$. wallace $i$ has a lower index of the red series than the $P$. aiereba stingray. On the other hand $P$. motoro is a kind of intermediate patterns of red series, varied between the two species, but with greater similarity to the species $P$. aireba.

We can observe in the PCA of Figure 2 (biochemistry plasma) the interaction between species $P$. wallace $i$ and

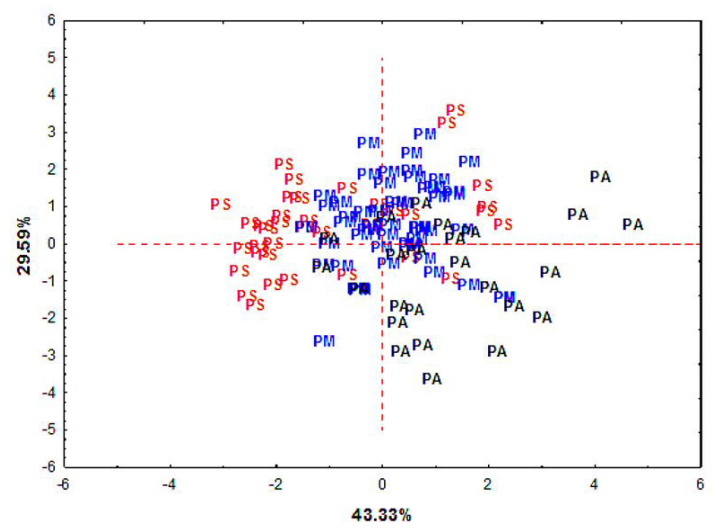

Figure 1. PCA of the complete blood counts of $P$. wallacei (PS), P. motoro (PM) and $P$. aiereba (PA) specimens caught in the midsection of the Negro River, Amazonas, Brazil.

Table 1. Mean values \pm standard deviation for the biometry of neonate and young Potamotrygon wallacei, Potamotrygon motoro and Paratrygon aiereba stingrays from the midsection of the Negro River, Amazonas, Brazil.

\begin{tabular}{cccc}
\hline Variables & P. wallacei & P. motoro & P. aiereba \\
\hline Disc width $(\mathrm{cm})$ & $8.88 \pm 1.60$ & $23.30 \pm 5.40$ & $23.54 \pm 3.99$ \\
Total length $(\mathrm{cm})$ & $16.78 \pm 2.37$ & $40.37 \pm 9.02$ & $38.05 \pm 7.41$ \\
Body mass $(\mathrm{g})$ & $46.80 \pm 22.57$ & $654.90 \pm 451.21$ & $641.20 \pm 289.19$ \\
\hline
\end{tabular}




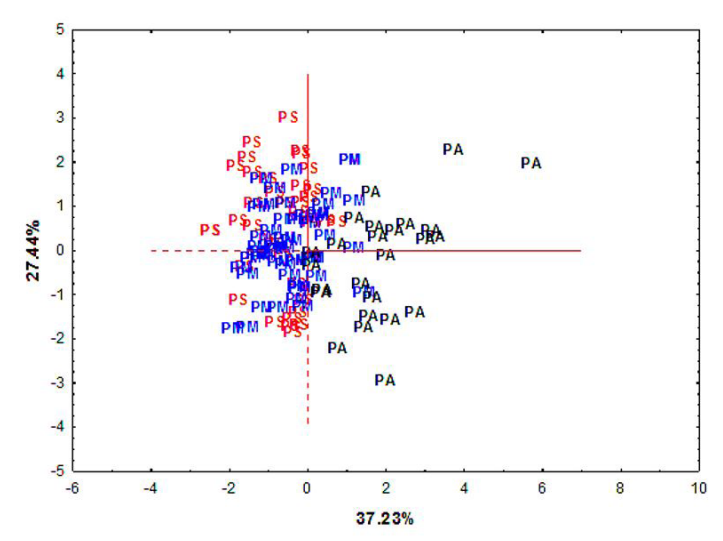

Figure 2. PCA on the plasma biochemistry of $P$. wallacei (PS), P. motoro (PM) and P. aiereba (PA) caught in the midsection of the Negro River, Amazonas, Brazil.

P. motoro, which differ considerably from P. aiereba to the axis $\mathrm{X}$. The ions are represented in Figure 3, for effective examination, it is necessary that the sum of $\mathrm{X}$ and $\mathrm{Y}$-axes are higher than $60 \%$. For the ions, these values have not reached the minimum level for the analysis $(50.62 \%)$. The same applies to figures for the PCA thrombogram and white blood cells (57.43\%) (Figure 4).

The data presented in Figure 5 demonstrate the PCA of water properties of the places where the stingrays were caught, showing that there was differentiation of $68.57 \%$, mainly along the $\mathrm{X}$-axis $(49.44 \%)$. These values indicate that the species $P$. motoro is distributed broadly across the environment, while the species $P$. aireba interacts more narrowly over the positive portion of the $\mathrm{X}$-axis.

\section{Discussion}

The PCA on the complete blood counts (Figure 1) constitutes a system of differentiated demand for oxygen, given that studies that investigated the complete blood count in freshwater stingrays have correlated the red series with respiratory activity and capacity (Brito et al., 2015; Oliveira et al., 2015c). P. wallacei presented clear differentiation in the $\mathrm{X}$ axis, in relation to $P$. aiereba. In turn, P. motoro was shown to be an intermediate species that presented complete blood count characteristics that interacted both with P. wallacei and with P. aiereba. Oliveira (2013) reported differences in habitats among these three species, such that $P$. wallacei presented preference for areas of igapós (typical Amazon submerged vegetation), P. aiereba preferred beaches and $P$. motoro inhabited areas that were intermediate between the igapós and beaches, which are classified as muddy-bottom areas. These characteristics of differentiation of the preferred environment corroborate the PCA obtained in the present study and confirm that these species can be differentiated with regard to the variables of the complete blood count.

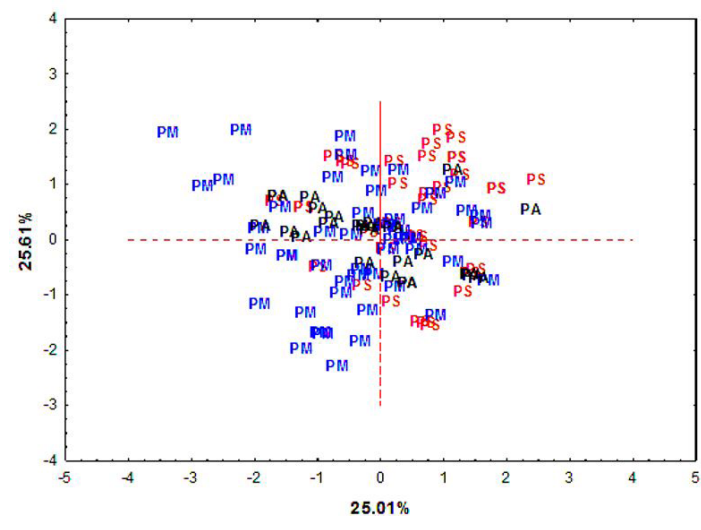

Figure 3. PCA on the ions of P. wallacei (PS), P. motoro (PM) and $P$. aiereba (PA) caught in the midsection of the Negro River, Amazonas, Brazil.

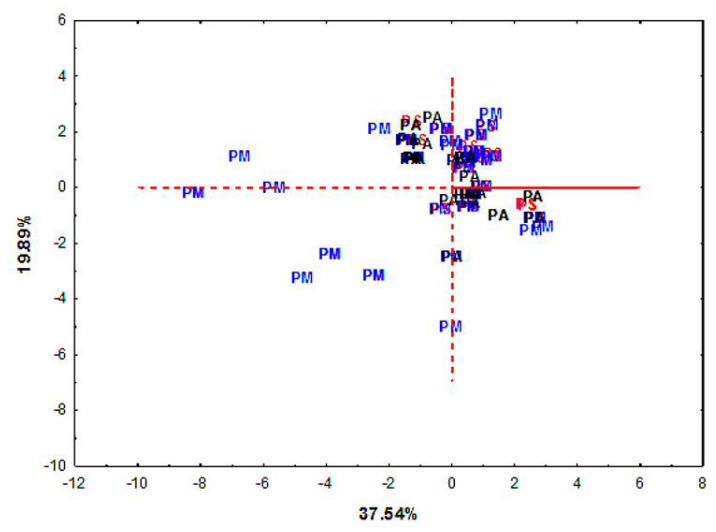

Figure 4. PCA of the thrombogram and white blood cell count of $P$. wallacei (PS), P. motoro (PM) and P. aiereba (PA) caught in the midsection of the Negro River, Amazonas, Brazil.

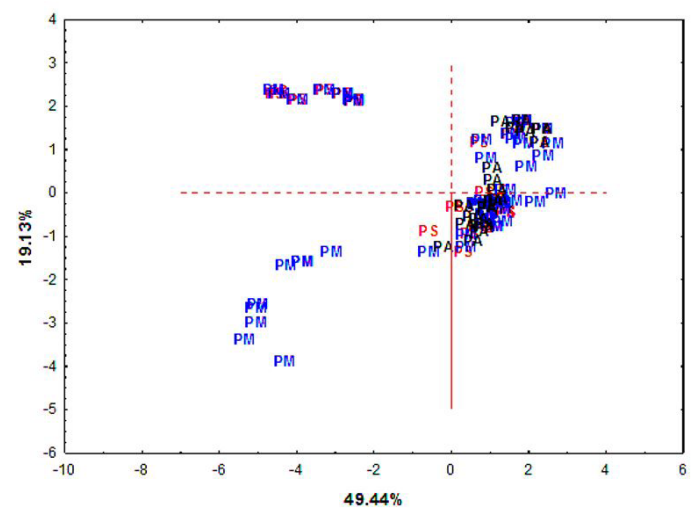

Figure 5. PCA of the water properties at the localities where P. wallacei (PS), P. motoro (PM) and P. aiereba (PA) were caught in the midsection of the Negro River, Amazonas, Brazil. 
The interaction among the biochemical variables (Figure 2) demonstrated that a total of $64.67 \%$ of the factors could be differentiated, with regard to the $\mathrm{X}$ axis. The greatest differentiation was between $P$. wallacei and $P$. aiereba, while $P$. motoro demonstrated characteristics closer to those of $P$. wallacei. However, P. motoro still presented an intermediate position between the other two species, similar to the results found with the complete blood count, which was associated with the preferential habitat and also the feeding preferences (Shibuya et al., 2009; Oliveira et al., 2015c). Regarding the ion values, the three species presented similarity to each other. This was also reported by Oliveira (2013) and was corroborated by the study by Duncan et al. (2009), considering that the waters of the Negro River present low ion concentrations (Duncan and Fernandes, 2010).

Thus, the immunological systems of the $P$. wallacei, $P$. motoro and $P$. aiereba stingrays cannot be considered to be different. This characteristic was also described by Oliveira et al. (2015c), who affirmed that the systems were conservative in nature. However, according to the data presented (Figure 4), it is clear that although P. motoro presents a pattern that is similar to that of the other species, there are also some different features that are not found in the other species. This could be due to adjustments to the immunological system of this species, considering that $P$. motoro is frequently caught in the areas that are preferred by $P$. wallacei and $P$. aiereba.

According to the data obtained (Figure 5), it can be confirmed that $P$. motoro has the capacity to inhabit the areas of $P$. wallace $i$ and $P$. aiereba. This plasticity demonstrates that $P$. motoro tolerate different physicochemical properties in water. The $P$. aireba species has distribution restriction on the favorable properties of water being present such as sandy soil areas (beaches). The species $P$. wallacei presents distributed in areas where the properties of water are considered unfavorable, this species occurs mainly in areas with litter (biomass).

The present study demonstrates the integration among the biological, ecological and hematological characteristics and water properties of the localities that freshwater stingrays inhabit in the Amazon basin. This makes it possible to conclude that $P$. wallacei presents distribution patterns that are differentiated from those of $P$. aiereba. Moreover, $P$. motoro presents intermediate characteristics between those described for the other species. Thus, P. motoro can be considered as a more broadly distributed species regarding its ecophysiological characteristics. This information can be used in investigations regarding species management and conservation.

\section{Acknowledgements}

This work was financed by the Federal University of Amazonas (Universidade Federal do Amazonas, UFAM), the Research Support Foundation of the State of Amazonas (Fundação de Amparo à Pesquisa do Estado do Amazonas, FAPEAM, under procedural nos. 925/03, 2203/05, 2204/05,
2459/08, 126/08 and 062.02583/14) and the National Council for Scientific and Technological Development (Conselho Nacional de Desenvolvimento Científico e Tecnológico, CNPq, under procedural nos. 486289/2006-0, 40872/2006-4 and 408795/2006-9). The main author is grateful for the doctoral degree scholarship granted by the Coordination Office for Improvement of University-level Personnel (Coordenação de Aperfeiçoamento de Pessoal de Nível Superior, CAPES) and is a research fellowship recipient from IFAM/Brazil. M. Tavares-Dias and J.L. Marcon are research fellowship recipients from $\mathrm{CNPq} / \mathrm{Brazil}$.

\section{References}

ARAÚJO, M.L.G., 1998. Biologia reprodutiva e pesca de Potamotrygon sp. (Chondrichthyes - Potamotrygonidae) no médio Rio Negro, Amazonas. Manaus: Instituto Nacional de Pesquisas da Amazônia, 171 p. Dissertação de Mestrado em Biologia de Água Doce e Pesca Interior.

ARAÚJO, M.L.G., 1999. Plano de Monitoramento de arraias de água Doce. Manaus: UFAM. 31 p.

ARAÚJO, M.L.G., 2011. Dinâmica de população e conservação de Paratrygon aiereba (Chondrichthyes-Potamotrygonidae) no médio Rio Negro, Amazonas. Manaus: Universidade Federal do Amazonas, 106 p. Tese de Doutorado em Diversidade Biológica.

BOYD, C.E. and TUCKER, C.S., 1992. Water quality and pond soil analyses for aquaculture. Auburn: Auburn University. 183 p.

BRASIL. Ministério do Meio Ambiente. Instituto Brasileiro do Meio Ambiente e dos Recursos Naturais Renováveis - IBAMA, 2008. Instrução Normativa $n^{\circ} 204$, de 22 de outubro de 2008. Diário Oficial da República Federativa do Brasil, Brasília, 27 out. 2008.

BRITO, F.M.M., CLAUDIANO, G.S., YUNIS, J., MUNDIM, A.V., TAVARES-DIAS, M., VIADANNA, P.H.O., MORAES, J.R.E. and MORAES, F.R., 2015. Hematology, biochemical profile and thyroid hormones of four species of freshwater stingrays of the genus Potamotrygon. Brazilian Journal of Veterinary Research and Animal Science, vol. 52, no. 3, pp. 249-256. http://dx.doi. org/10.11606/issn.1678-4456.v52i3p249-256.

CARVALHO, M.R., ROSA, R.S. and ARAÚJO, M.L.G., 2016. A new species of Neotropical freshwater stingray (Chondrichthyes: Potamotrygonidae) from the Rio Negro, Amazonas, Brazil: the smallest species of Potamotrygon. Zootaxa, vol. 4107, no. 4, pp. 566-586. PMid:27394840. http://dx.doi.org/10.11646/ zootaxa.4107.4.5.

CHARVET-ALMEIDA, P., ARAÚJO, M.L.G. and ALMEIDA, M.P., 2005. Reproductive aspects of freshwater stingrays (Chondrichthyes: Potamotrygonidae) in the Brazilian Amazon basin. Journal of Northwest Atlantic Fishery Science, vol. 35, pp. 165-171. http://dx.doi.org/10.2960/J.v35.m502.

DUNCAN, W.P. and FERNANDES, M.N., 2010. Physicochemical characterization of the white, black, and clearwater rivers of the Amazon Basin and its implications on the distribution of freshwater stingrays (Chondrichthyes, Potamotrygonidae). Pan-American Journal of Aquatic Sciences, vol. 5, pp. 454-464.

DUNCAN, W.P., COSTA, O.T.F., ARAÚJO, M.L.G. and FERNANDES, M.N., 2009. Ionic regulation and $\mathrm{Na}^{+}-\mathrm{K}^{+}$-ATPase activity in gills and kidney of the freshwater Paratrygon aiereba living in white and blackwaters in the Amazon Basin. Journal of 
Fish Biology, vol. 74, no. 4, pp. 956-960. PMid:20735610. http:// dx.doi.org/10.1111/j.1095-8649.2008.02156.x.

OLIVEIRA, A.T., 2013. Parâmetros hematológicos, aspectos citoquímicos e ultraestruturais das células sanguíneas de três espécies de arraias de água doce (Chondrichthyes: Potamotrygonidae) do Arquipélago de Mariuá, Amazonas. Manaus: Universidade Federal do Amazonas, 202 p. Tese de Doutorado em Diversidade Biológica.

OLIVEIRA, A.T., LEMOS, J.R.G., SANTOS, M.Q.C., ARAÚJO, M.L.G., TAVARES-DIAS, M. and MARCON, J.L., 2012. Procedimentos de manuseio e de colheita do sangue em arraias. Macapá: Embrapa Amapá. 18 p.

OLIVEIRA, A.T., LIMA, E.C., PAES, L.S., SANTOS, S.M., ARAÚJO, R.L., PANTOJA-LIMA, J. and ARIDE, P.H.R., 2015a. Relações entre as populações naturais de arraias de água doce (Myliobatiformes: Potamotrygonidae) e pescadores do baixo rio Juruá, Amazonas, Brasil. Biota Amazônia, vol. 5, no. 3, pp. 108-111. http://dx.doi.org/10.18561/2179-5746/biotaamazonia. v5n3p108-111.

OLIVEIRA, A.T., PANTOJA-LIMA, J., ARIDE, P.H.R., TAVARESDIAS, M. and MARCON, J.L., 2015c. Fisiologia de arraias de água doce: subsídios para aplicabilidade na aquicultura. In: M. TAVARES-DIAS and W.S. MARIANO, orgs. Aquicultura no Brasil: novas perspectivas. São Carlos: Pedro \& João, v. 1, pp. 45-74.
OLIVEIRA, A.T., SANTOS, M.Q.C., LEMOS, J.R.G., PANTOJALIMA, J., ARIDE, P.H.R., TAVARES-DIAS, M. and MARCON, J.L., 2015b. Comparison of the effects of anticoagulants used in blood collection for the determination of blood parameters of free-living stingrays of the Potamotrygon genus (Elasmobranchii: Potamotrygonidae). Biota Amazônia, vol. 5, no. 3, pp. 55-58. http://dx.doi.org/10.18561/2179-5746/biotaamazonia.v5n3p55-58.

SANCHEZ-DUARTE, P., LASSO, C.A., ORTIZ-ARROYAVE, L.M., MORALES-BETANCOURT, M.A., LOBODA, T.S., CARVALHO, M.R., ACOSTA-SANTOS, A., AGUDELOCORDOBA, E., BONILLA-CASTILLO, C.A., GOMEZHURTADO, G.A., BARRIGA, R. and ORTEGA, H., 2014. Familia Potamotrygonidae - Potamotrygon motoro - Cuenca del Amazonas. In: C.A. LASSO, R.S. ROSA, P. SÁNCHEZ-DUARTE, M. A. MORALES-BETANCOURT and E. AGUDELO-CÓRDOBA, orgs. Rayas de Agua Dulce (Potamotrygonidae) de Suramérica. vol. 1, pp. 218-223.

SHIBUYA, A., ARAÚJO, M.L.G. and ZUANON, J., 2009. Analysis of stomach contents of freshwater stingrays (Elasmobranchii: Potamotrygonidae) from the middle Negro River, Amazonas, Brazil. Pan-American Journal of Aquatic Sciences, vol. 4, no. 4, pp. 466-475.

TAVARES-DIAS, M. and MORAES, F.R., 2006. Hematological parameters for the Brycon orbignyanus, 1850 (Osteichthyes: Characidae) intensively bred. Hidrobiológica, vol. 16, no. 3, pp. 273-276. 